\title{
Extraction of Coconut Oil from Coconut Milk Foulants Using Enzyme
}

\author{
Phanida Saikhwan ${ }^{1, a}$, Chanokchat Nuchnet ${ }^{1}$, Wannakarn Wanakayont ${ }^{1}$, Angkana Suksa-nga ${ }^{1}$ \\ ${ }^{1}$ Thammasat University, Thailad
}

\begin{abstract}
Coconut milk manufacturing process encounters problems with foulants formed during pasteurization process. For example, fouling layers reduce heat transfer efficiency of a heat exchanger. As the fouling layers are considered as waste, this research aimed at extracting coconut oil from the foulants to produce a product from the waste. A model coconut milk foulant was used to simulate foulants formed during batch pasteurization process and coconut oil was extracted from the foulant using celloulase enzyme. The extracted oil then was evaluated in terms of fatty acid composition and antioxidant properties (total phenolic and flavonoid contents). The antioxidant activities were evaluated using DPPH (1,1-diphenyl-2-picrylhydrazyl) radical scavenging and FRAP (Ferric reducing antioxidant power) methods. Results showed that the oil extracted from the foulants appeared similar to virgin coconut oil (VCO); the extracted oil appeared as clear viscous liquid with aroma associated with roasted coconut. The oil extracted using enzyme contained all fatty acids found in VCO in lower proportions but large extent of linoleic acid was found. Antioxidant capacity was similar to that of VCO. The foulants after the extraction of fat using enzyme were easier to clean suggesting the possibility to couple cleaning of coconut milk foulants and oil extraction in the same process.
\end{abstract}

\section{Introduction}

Nowadays, most coconut milk manufactures encounter problems with foulants formed during pasteurization process. Fouling is generally defined as the accumulation and formation of unwanted materials on the surfaces of processing equipment, which leads to reduction in heat transfer efficiency. Other problems associated with foulants are loss of energy, cost of maintenance, cost of cleaning, and waste management.

Coconut milk foulants contain fat in large proportion and the extracted fat has physical properties (colour and aroma) similar to virgin coconut oil (VCO) [1]. VCO is distinguished from another type of coconut oil (Refined, Bleached and Deodorized: RBD) by its colour (colourless) and a coconut aroma. In addition, VCO contains a large amount of medium-chain fatty acids such as lauric, capric, caproic and caprylic acids which were reported to have antimicrobial and antiviral effects [2]. It has been claimed that VCO has several beneficial health effects such as antioxidant capacity and high level of vitamin E [3-6]. Extracting coconut oil from coconut milk foulants using petroleum ether yielded oil with fatty acid profile lying in the standard accepted for VCO [7]. Although the extracted oil had comparable antioxidant capacity to virgin olive oil, the antioxidant capacity was on the lower bound reported for VCO [7]. The lower antioxidant capacity observed with the coconut oil extracted from coconut milk foulants using petroleum ether could be due to the exposure to the chemical and high temperature used during the extraction.

\footnotetext{
a Corresponding author: psaikhwan@engr.tu.ac.th
}

Recently, enzymes have been employed in oil extraction, e.g. extraction of sesame oil [8], extraction of peanut oil [9], and extraction of oil from coconut meat [10]. Major benefit of using enzymes in oil extraction that have been reported is that quality of oil is not altered by the mild condition used during the extraction [11]. Enzymes have also been used in cleaning of milk foulants $[12,13]$. The efficiency was reported to be comparable to that of chemical cleaning and using enzyme is more environmental friendly. Hence, this work aimed to investigate properties of coconut oil extracted from coconut milk foulants using enzyme. As extracting oil during cleaning would be more practical for use with a continuous pasteurization process, this paper also reported results of preliminary study of possibility of combining the oil extraction using enzyme with cleaning of the foulants.

\section{Materials and Methods}

\subsection{Preparations of coconut milk foulants}

Fresh grated coconuts were purchased from local markets and coconut milk was extracted by mixing $500 \mathrm{~g}$ grated coconut meat with $200 \mathrm{ml}$ distilled water. The coconut milk was used to prepare a model coconut milk foulant using the method reported by [14] where pasteurization was conducted using lab-scaled apparatus simulating batch and continuous pasteurization processes (Figure 1). 
To produce foulants from a batch pasteurization, coconut milk was heated in a container (Figure 1(a)) placing on a hot plate. Three sample plates (SS304) were placed at the bottom of the container where foulants were formed. An overhead stirrer (100 rpm) was used to improve heat transfer and prevent film forming at a surface of coconut milk. The coconut milk was heated from a room temperature and once the milk reached $70^{\circ} \mathrm{C}$, temperature was controlled at this temperature and heating was continued for 20 minutes. After that the coconut milk was poured away and sample plates with coconut milk foulants formed on the plates were removed.

The apparatus used to simulate a continuous pasteurization (Figure 1(b)) is a heat exchanger with sample plates separating coconut milk flow $(0.048 \mathrm{~m} / \mathrm{s})$ and hot water $\left(95^{\circ} \mathrm{C}\right)$. To produce the foulants, coconut milk was preheated (in a beaker immersed in hot water at $50^{\circ} \mathrm{C}$ ) and was fed into the heat exchanger. Thermocouples were used to monitor temperatures of the system. At steady state, coconut milk temperature was at $70^{\circ} \mathrm{C}$ and the process was continued for 20 minutes after that. At the end of pasteurization, coconut milk was drained out and sample plates with coconut milk deposits were collected.

(a)

(b)
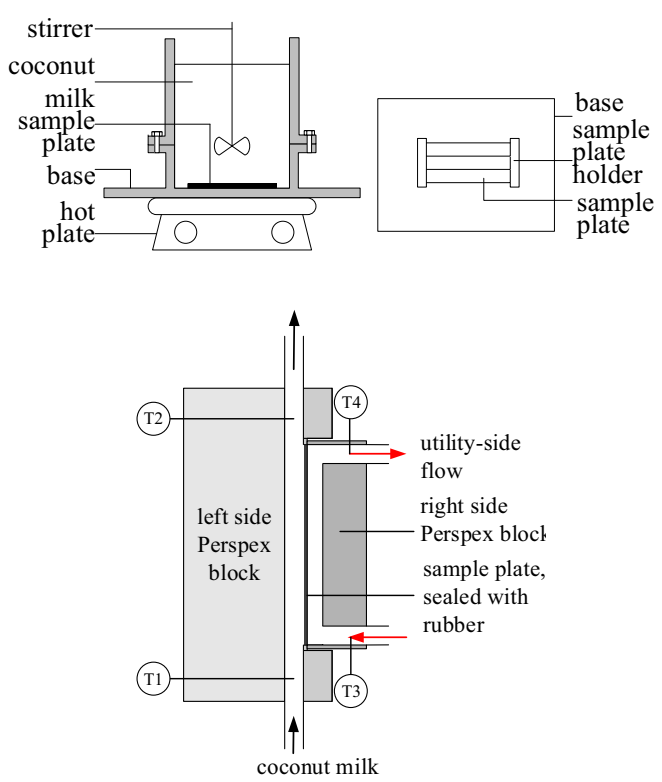

Figure 1. Schematic of apparatus used in formation of coconut milk foulants: (a) batch process; (b) continuous process (T1-T4 are thermocouples used for temperature monitoring).

\subsection{Oil extraction}

Since coconut milk foulants contain carbohydrate which is hard to remove during cleaning [14], celloulase (Brentag, Thailand) was chosen as the enzyme used to extract coconut oil in this study. The extraction protocol was modified from the protocol used by [7] where celloulase was employed in oil extraction from sesame seeds.

First, foulants obtained from a model batch pasteurizer were scraped from sample plates. Distilled water was added to the foulants at a ratio of $3 \mathrm{ml}$ of water per $1 \mathrm{~g}$ of foulant. Then this mixture was boiled for 10 minutes and left to cool down to room temperature. Celloulase then was added to the mixture. Varying ratios of celloulase mass to foulant mass $(2-20 \%)$ were used in order to find the optimum enzyme-to-foulant mass ratio. After adding the enzyme, if $\mathrm{pH}$ of the mixture was not in a range of $\mathrm{pH}$ 5.0-5.5 (optimum $\mathrm{pH}$ of celloulase activity), $\mathrm{pH}$ of the mixture would be adjusted using $0.2 \mathrm{~N} \mathrm{HCl}$. The mixture containing water, foulant and enzyme was then placed in a hot water bath $\left(45-50^{\circ} \mathrm{C}\right)$ for 2 hours and left overnight. Finally, the mixture was centrifuged and oil layer was found. The oil was then obtained and kept for further testing.

As amounts of oil extracted using different enzymeto-foulant mass ratios showed that the ratio of $6 \%$ was the optimum ratio (See 3.1), only this ratio was used in oil extraction from coconut milk foulants from a continuous pasteurization. The extraction steps were the same as those used in the extraction from the foulants from a batch pasteurization.

\subsection{Characterization of extracted oils}

\subsubsection{Determination of fatty acid profiles}

Determination of fatty acids was supplied by The Institute of Biotechnology and Genetic Engineering (IBGE), Chulalongkorn University, Thailand. Preparation of fatty acid methyl ester (FAME) was carried out according to IUPAC standard method 2.301 (IUPAC, 1979) and FAME standards used in this analysis were obtained from an AccuStandard. FAME was determined on an Agilent Technologies $6890 \mathrm{~N}$ gas chromatography equipped with INNOWAX capillary column $(30 \mathrm{~m} \times 0.3$ $\mathrm{mm}$ i.d., $0.25 \mu \mathrm{m}$ film thickness) and a Flame Ionization Detector (FID) system. The injector and detector temperatures were set at $150^{\circ} \mathrm{C}$ and $250^{\circ} \mathrm{C}$, respectively. Helium was used as the carrier gas at a flow rate of 2.3 $\mathrm{mL} / \mathrm{min}$. The Gas Chromatographic temperature was set as follows: initial temperature of $150^{\circ} \mathrm{C}$, increasing to $180^{\circ} \mathrm{C}$ at $10^{\circ} \mathrm{C} / \mathrm{min}$, then to $200^{\circ} \mathrm{C}$ at $5^{\circ} \mathrm{C} / \mathrm{min}$ and then held for $5 \mathrm{~min}$ (total runtime of $33 \mathrm{~min}$ ). Individual FAMEs were identified by comparison with reference standards [15].

\subsubsection{Antioxidant capacity measurements}

Antioxidant capacity of the extracted oil was measured using DPPH (2, 2-diphenyl-1-picrylhydrazyl) radical scavenging assay, FRAP (Ferric reducing antioxidant power) assay and determination of total phenolic and determination of flavonoid content. The antioxidant capacity measurements were supplied by Excellent Center for Cosmetic and Wellness (ECCW), Mae Fah Luang University, Thailand.

\subsection{Preliminary study of extracting oil and cleaning coconut milk foulants using enzyme}

In practice, it is not possible to remove foulants from a continuous pasteurizer (or a heat exchanger) manually 
before extracting oil from the foulants. So celloulase was mixed with water at $6 \%$ by weight and was fed into a continuous pasteurizer (with foulants inside) to simulate Cleaning-In-Place (CIP), a cleaning process generally used in cleaning of a heat exchanger. This experiment, hence, studied the possibility of cleaning the foulants and extracting oil during the cleaning.

The CIP protocol used in this study involves: (i) soaking the mixture of water and enzyme in the heat exchanger fouled with coconut milk deposits at $45-50^{\circ} \mathrm{C}$ for 2 hours and (ii) circulating the mixture in the heat exchanger and observe any removal of foulants. CIP studies were also conducted using water as circulating fluid.

In addition, swelling studies of the deposits soaked in the enzyme solution were conducted to elucidate effects of enzyme on cleaning of the foulants. The swelling studies were done using a gravimetric method. A deposit was immersed in a beaker containing the enzyme solution and it mass was measured at every 5 minutes for 2 hours. Before weighing the deposit, excess liquid was removed from the deposit using filter paper.

\section{Results}

\subsection{Optimum enzyme-to-foulant mass ratio}

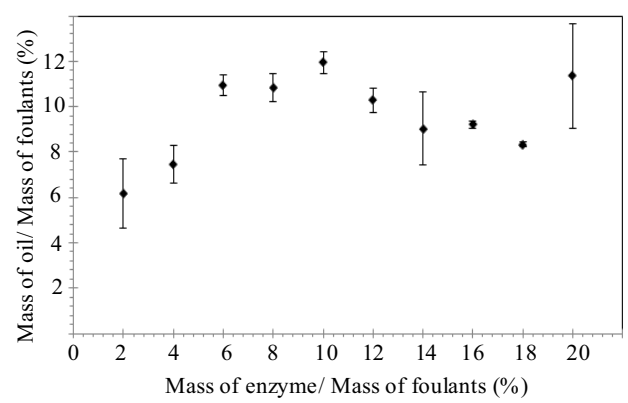

Figure 2. Amounts of oil extracted from coconut milk foulants using different enzyme-to-foulants mass ratios.

Figure 2 depicts oil yields from using various enzyme-to-foulants mass ratios (2-20\%). According to the figure, there is a peak at enzyme-to-foulants mass ratio of $10 \%$ and when enzyme-to-foulants mass ratio increases beyond $10 \%$, there is a drop in oil yield. The yield then rises again at enzyme-to-foulants mass ratio of $20 \%$. The initial increase in oil yield at enzyme-tofoulants mass ratios below $10 \%$ could be because there was unused substrate in the foulants. Hence, when more enzyme was added, more oil was obtained. It was also observed that when more enzyme was used, foulants were digested to smaller size. As foulants acted as a barrier between oil layer and aqueous layer (Figure 3), a layer of foulants that were digested to small sizes was quite unstable. Consequently, it was more difficult to remove all oil without interfering the foulants and aqueous layers. Some oil was also in the digested foulants layer. This explains the drop in oil yield and varying results when enzyme-to-foulants mass ratio was higher than $10 \%$.

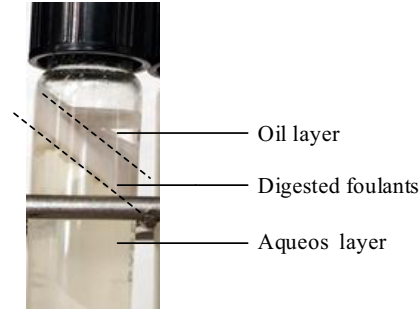

Figure 3. A mixture of foulants, enzyme and water after centrifugation (Dotted line shows a foulant layer).

Consider the results in Figure 2, enzyme cost and the ease of removing an oil layer, it was decided that the optimum enzyme-to-foulants mass ratio was $6 \%$. The extraction yield was approximately $11 \%$. This is quite low compared to the yield obtained when extracting using petroleum ether $(50 \%$ [6]). The low yield is typical in extracting oil using enzymes [7-9].

\subsection{Properties of extracted oils}

\subsubsection{Fatty acid profiles}

Table 1 shows fatty acid profiles of various samples of coconut oil. As fatty acid profiles of oil extracted using enzyme from foulants found in batch and continuous pasteurizer were comparable, their profiles are reported as a profile of oil extracted using enzyme in the table.

Table 1. Fatty acid profiles of coconut oil samples extracted from coconut milk foulants using enzyme and petroleum ether compared with fatty acid profile of APPC standards for VCO.

\begin{tabular}{|l|c|c|c|}
\hline $\begin{array}{l}\text { Fatty } \\
\text { acids }\end{array}$ & $\begin{array}{l}\text { Oil extracted } \\
\text { using enzyme }\end{array}$ & $\begin{array}{l}\text { Oil extracted } \\
\text { using petroleum } \\
\text { ether [6] }\end{array}$ & $\begin{array}{l}\text { APPC } \\
\text { standards } \\
\text { for VCO }\end{array}$ \\
\hline C6:0 & - & - & $0.4-0.6$ \\
\hline C8:0 & $5.01 \pm 1.32$ & $7.10 \pm 0.03$ & $5.0-10.0$ \\
\hline C10:0 & $4.32 \pm 0.86$ & $5.88 \pm 0.08$ & $4.5-8.0$ \\
\hline C12:0 & $32.26 \pm 2.44$ & $45.84 \pm 1.36$ & $45.1-53.2$ \\
\hline C14:0 & $12.25 \pm 0.41$ & $17.91 \pm 0.23$ & $16.8-21.0$ \\
\hline C14:1 & $1.25 \pm 0.36$ & - & NA \\
\hline C15:0 & - & 0.38 & NA \\
\hline C16:0 & $5.64 \pm 0.59$ & $8.24 \pm 0.36$ & $7.5-10.0$ \\
\hline C16:1 & - & $0.35 \pm 0.01$ & NA \\
\hline C18:0 & $1.76 \pm 0.36$ & $2.24 \pm 0.38$ & $2.0-4.0$ \\
\hline C18:1 & $3.53 \pm 0.44$ & $5.48 \pm 0.51$ & $5.0-10.0$ \\
\hline C18:2 & $19.13 \pm 2.71$ & $3.06 \pm 0.01$ & $1.0-2.5$ \\
\hline C22:2 & $2.53 \pm 0.30$ & - & $\begin{array}{c}<0.5 \\
(\mathrm{C} 18: 3- \\
\text { C224:1 }\end{array}$ \\
\hline Other & 4.33 & 0.1 & NA \\
\hline
\end{tabular}


While the fatty acid profile of the oil extracted from foulants using petroleum ether fits the APPC standards quite well, the fatty acid profile of the oil extracted using enzyme had lower contents of the fatty acids specified in the standards. This could be because other fatty acids not specified in the standards were found in the oil extracted using enzyme. These other fatty acids have been reported for health benefits. For instance, myristoleic acid (C14:1) has been reported to have activity against prostate-cancer cells [16]. Docosadienoic acid (C22:2) is an essential polyunsaturated fatty acid in a group of omega 6 fatty acids which has a high nutritive value [17]. It should also be noted that the oil extracted using enzyme contained strikingly large content of linoleic acid (C18:2). In a recent study, intake of linoleic acid can reduce total and LDL cholesterol, improve insulin sensitivity and blood pressure and lower risk of coronary disease $[18,19]$.

\subsubsection{Antioxidant capacity}

Table 2. Antioxidant capacities of coconut oil obtained from coconut milk foulants using enzyme (EB-from batch pasteurization; EC-from continuous pasteurization) compared with that of coconut oil obtained from an extraction from foulants from a batch pasteurization using petroleum ether (PEB) and results from the literature.

\begin{tabular}{|c|c|c|c|c|}
\hline \multirow{2}{*}{$\begin{array}{c}\text { Oil } \\
\text { sample }\end{array}$} & \multicolumn{2}{|c|}{ Antioxidant activity } & \multirow{2}{*}{$\begin{array}{c}\text { Total } \\
\text { phenolic } \\
\text { mgGAE/g }\end{array}$} & \multirow{2}{*}{$\begin{array}{c}\text { Flavono } \\
\text { d conten } \\
\mathrm{mgQE} / \mathrm{g}\end{array}$} \\
\hline & $\begin{array}{c}\text { DPPH } \\
\text { mgTEAC/g }\end{array}$ & $\begin{array}{c}\text { FRAP } \\
\text { mgTEAC/g }\end{array}$ & & \\
\hline EB & $\begin{array}{c}0.934 \\
\pm 0.066 \\
\end{array}$ & $\begin{array}{c}1.699 \\
\pm 0.00416 \\
\end{array}$ & $\begin{array}{c}0.196 \\
\pm 0.009 \\
\end{array}$ & $\begin{array}{c}6.491 \\
\pm 0.882 \\
\end{array}$ \\
\hline $\mathrm{EC}$ & $\begin{array}{c}0.126 \\
\pm 0.016\end{array}$ & $\begin{array}{c}0.571 \\
\pm 0.034 \\
\end{array}$ & $\begin{array}{c}0.169 \\
\pm 0.005 \\
\end{array}$ & $\begin{array}{c}0.132 \\
\pm 0.009 \\
\end{array}$ \\
\hline PEB [6] & $\begin{array}{c}0.079 \\
\pm 0.0296\end{array}$ & $\begin{array}{c}0.935 \\
\pm 0.071 \\
\end{array}$ & $\begin{array}{c}0.061 \\
\pm 0.006 \\
\end{array}$ & $\begin{array}{c}0.546 \\
\pm 0.015\end{array}$ \\
\hline $\begin{array}{l}\text { VCO } \\
{[20,21]}\end{array}$ & 0.154 & NA & $\begin{array}{l}0.078- \\
0.29 \\
\end{array}$ & NA \\
\hline
\end{tabular}

From Table 2, consider antioxidant capacities of EB and $\mathrm{PEB}$, it can be concluded that the extraction using petroleum ether significantly reduced antioxidant capacity of the oil. It can also be seen that coconut oil extracted from foulants from a batch pasteurization generally had higher antioxidant capacity compared to the oil from foulants from a continuous process. Particularly, flavonoid contents found in both EB and BPE (both samples were extracted from foulants found in a batch pasteurization) were larger than that associated with EC. As a wide spectrum polyphenolics from the class of flavonoids can be found in coconut oil $[22,23]$, the higher flavonoid content of EB compared to that of EC explains the slightly higher total phenolic content in the EB. Moreover, as it has been shown a positive relationship between total phenolic content and antioxidant activity measured by FRAP assay [24], the higher activity of EB measured by FRAP assay could be due to the higher total phenolic content of EB.
Nevertheless, it should be noted that antioxidant activity of EC obtained from DPPH assay was slightly higher than that of EB. Comparing antioxidant capacities of EB, EC and VCO reported by the literature, the oils extracted from foulants formed in batch and continuous pasteurizers had antioxidant capacities comparable to that of VCO.

\subsection{Preliminary results of cleaning coconut milk foulants using enzyme}

Two sets of CIP studies were done: (i) use the enzyme solution as a cleaning liquid and (ii) use water. At the same flow rate, an extent of removal of deposits observed with the use of enzyme was approximately 3 times of an extent of removal associated with CIP using water. It was also noticed that an onset of removal was observed at a flow rate of $163 \mathrm{~g} / \mathrm{s}$ whereas an onset of removal was observed at a flow rate of $435 \mathrm{~g} / \mathrm{s}$ and $372 \mathrm{~g} / \mathrm{s}$ when water and sodium hydroxide $(\mathrm{pH} 12)$ were used in cleaning respectively [14]. The results suggest that using enzyme could improve cleaning efficiency of foulants. In the cleaning effluent, oil film was observed. Hence, oil extraction also occurred during the cleaning.

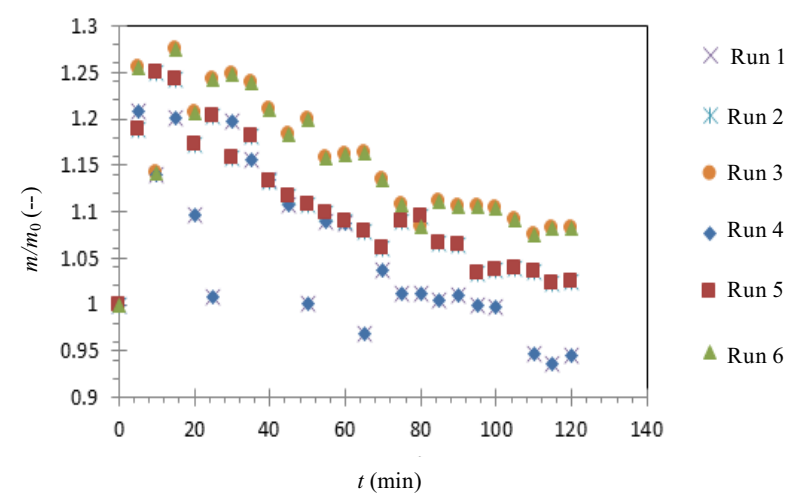

Figure 4. Swelling of coconut milk deposits (from a continuous pasteurization) in a mixture of celloulase and water: $m$ - mass of deposits; $m_{0}$ - initial mass of deposits; $t$ - time.

Swelling studies of coconut milk deposits in the mixture of enzyme and water are illustrated by Figure 4. An initial increase in mass was observed and then mass of the deposits decrease with soaking time. The decrease is due to removal of the deposits as some debris were observed during the swelling studies. The removal like this was not observed in swelling of coconut milk deposits in sodium hydroxide [14]. This is probably why cleaning efficiency seemed to be better when using enzyme in CIP studies.

\section{Conclusions}

Celloulase can be used to extract oil from coconut milk foulants formed during pasteurization of coconut milk. The oil contains all fatty acids found in VCO but at lower proportion. This is because the oil contains significantly larger content of linoleic acid and other fatty acids which have health benefits. 
Although the yield obtained when extracting oil using enzyme was lower than that obtained when using extraction with petroleum ether, antioxidant capacity of the oil was preserved when extracting using enzyme. The type of pasteurization also affects antioxidant capacity of the oil extracted. The oil extracted from foulants from a batch pasteurizer had higher antioxidant activity than the oil from foulants from a continuous pasteurizer. This could be because of more flavonoid content found in the oil from foulants formed in a batch pasteurizer.

Preliminary studies of cleaning of the foulants using enzyme suggest a better cleaning efficiency compared to cleaning by $\mathrm{NaOH}$, the typical chemical used in cleaning. The better efficiency was explained by digestion of the foulants by enzyme which helped removing the foulants during CIP. As oil film was observed in the cleaning effluents, oil was also extracted from the foulants during cleaning. Further work should be done to optimize the CIP using enzyme so that oil extraction and cleaning can be done in the same stage. This in turn will generate a useful product from waste, reduce cleaning cost/time and lower a load for wastewater treatment.

\section{References}

1. P. Saikhwan, S. Thongchan, Proceedings of World Academy of Science, Engineering and Technology (2013)

2. B.J. Villarino, D.L. Marsha, M. Concepc'ion, C. Lizada, LWT-Food Sci. Technol. 40, 193-199 (2007)

3. R. Arlee, R., S. Suanphairoch, P. Pakdeechanuan, Int Food Res. J. 20, 2103-2109 (2013)

4. D.D. Bawalan, K.R. Chapman, Virgin Coconut Oil production manual for micro- and village-scale processing. FAO Regional Office for Asia and the Pacific (2006)

5. A.S. Librado, M.V. Von Luigi, Int. Food Res. J. 20, 1683-1689 (2013)

6. K.N. Seneviratne, C.D. Hapuarachchl, S. Ekanayake, Food Chem. 114, 1444-1449 (2009)

7. P. Saikhwan, K. Jarungsorasak, V. Opaspong, C. Nuchnet, W. Wanakayont, A. Suksa-nga, Proceedings of ICEAS (2015)
8. S. Latif, F. Anwar, Food Chem. 125, 679-684 (2010)

9. D.H.L. Jiang, Z. Wang, S. Xu, Food Bioprod. Process. 88, 233-238 (2010)

10. Y.O.K. Tano-Debrah, J. Sci. Food Agric. 74, $497-$ 502 (1997)

11. H.B. Petrus, H.L.V. Chen, N. Norazman, J. Membr. Sci. 325, 783-792 (2008)

12. A. Grasshoff Food Bioprod. Process. 88, 233-238 (2002)

13. A. Boyce, A.V. Piterina, G. Walsh, Biofouling 26(7), 837-850 (2010)

14. P. Saikhwan, S. Thongchan, N. Jumwan, P. Thungsiabyuan, J. Sakdanuphap, S. Boonsom, P. Kraitong, P. Danwanichakul, Food and Bioprod. Process. 93, 166-175 (2015)

15. M. Limsuwatthanathamrong, S. Sooksai, S. Chunhabundit, S. Noitung, N. Ngamrojanavanich, A. Petsom, Asian J. Anim. Sci. 6, 65-72 (2012)

16. K. Iguchi, N. Okumura, S. Usui, H. Sajiki, K. Hirota, K. Hirano, Prostate 47(1), 59-65 (2001)

17. F. Jabeen, A.S. Chaudhry, Food Chem. 125(1), $991-$ 996 (2011)

18. M.S. Farvid, M. Ding, A. Pan, Q. Sun, S.E. Chiuve, L.M. Steffen, W.C. Willett, F.B. Hu, Circulation 130(18), 1568-1578 (2014)

19. E. Phares, The nutrition source: Harvard T.H. Chan School of public health November 5 (2014)

20. A. M. Marina, Y. B. Che Man, I. Amin, Trends Food Sci. Tech. 20, 481-487 (2009)

21. K. Ratanapradit, S. Palakas, Determination of antiradicals and anti-oxidatioin reaction properties of virgin coconut oil and virgin coconut oil supplemented functional foods products, Burapha University, Thailand (2008)

22. K.G. Nevin, T. Rajamohan, Food Chem. 99(2), 260266 (2006)

23. K.G. Nevin, T. Rajamohan, e-SPEN 3(1), e1-e8 (2008)

24. K. Thaipong, Boonprakob, U., Crosby, K., L. Cisneros-Zevallos, D.H. Byrne, J. Food Compost. Anal. 19, 669-675 (2006) 